\title{
Effect of Street Hawking On the Academic Performance Of Students in Social Studies in Junior Secondary Schools in Nassarawa State, Nigeria
}

\author{
${ }^{1}$ Dr M.C. Ubah, ${ }^{2}$ Averson Bulus \\ ${ }^{1,2}$ Department Of Arts And Social Science Education Ahmadu Bello University, Zaria
}

\begin{abstract}
The study sought to find out the effect of street hawking on academic performance of students of social studies in Nasarawa state. The sample comprises of 100 JSS III students, 50 females and 50 males. Quasi-experimental post-test design was employed. Test item; Social studies performance test (SSPT) instrument was use. Using t-test statistics the result shows that: the experimental group exposed to hawking performed significantly lower than the control group who are not exposed. The performances mean score of the experimental group is 10.50 while the control group is 15.60. The study found that street hawking has negative effect on students' academic performance in social studies. It recommends that government should create more job opportunities so that children would not have to contribute to family income.
\end{abstract}

\section{Introduction}

Involving children in hawking goods in the street is an emerging trend in Nigeria and an issue of concern. This trend is refer to as; child street trading (Ashimolowo, Aromolaran \& Inegbedion, 2010), child street hawking (Mathias \& Dada, 2013), juvenile street hawking (Udoh \& Joseph, 2012) and child street vendor (Ugochukwu, Okeke, Onubogu \&Edokwe, 2012). Children are preferred to adult in hawking goods because; they are less criminal and a cheap labour to the employer (Arhedo, Aluede \&Arhedo, 2011; Anumaka, 2012).This led to increase in the number of children who roam the street daily hawking goods while those of their age are in school. Studies identified the age bracket of these children to fall between 10 and 19 years. (Ashimolowo, et al 2010; Ndem, Michiel, \& Awa, 2012; Ugochukwu, et al 2012). Most of this children hawk before going to school in morning and continue after until late night. Street hawking has left many children out of school as they drop out, withdrawn by their parent or not enroll. School age children estimated to be 10.5 million are out of school in Nigeria (The Guardian, 2013). Though, this is not surprising, giving that majority of the population are living below the poverty line couple with the fact that, these children are being engaged in income generating activities to contribute to the sustenance of the family, however, it is embarrassing to a country with abundant natural resources like Nigeria. Until this is addressed, achieving education millennium development goal remains an elusion.

Several studies exist on child street hawking with focus on behavioral problems (Udoh \& Joseph, 2013; Ugodulunwa, et.al 2004), child Abuse (Akpan \& Oluwabamide, 2010), Symptoms of Psychopathology (Ezenwa, 2011) and Socio-demographic characteristics (Ugochuku, et.al 2012). The present study intends to find out the effect of street hawking on academic performance of students in social studies, which is an indicator of students' progress in school as it, shows how high or low students achieved. Academic performance is a reflection of the education of the child (Anumaka, 2012) and it is the desire of parent, their children should achieved high.

Different factors are responsible for influencing academic performance of students. Studies, found some of these factors to be; students perception of teachers class room management (Okon, 2005), attendance in class (Nyame, 2010), learning environment (Ekanem, Apebende, \& Ekefre, 2011), financial status of parent, and poor method of teaching (Okoji, 2013). In spite of research findings on how to improve, academic performance of students, low performance and failure in examination has been reported. This indicates that, there is a need to carry out more research on students' academic performance. The finding of this study, it is hoped will help in cubing the problem of students' poor academic performance.

\section{Statement Of The Problem}

All junior secondary school, students, it is expected should revise their notes, do their homework, and rest after school to prepare them for the next day school activities which will improve their academic performance. It is been observed, however, not all the students revise their notes, do homework and rest after school hours. The students instead, engage in income generating activities such as selling goods after school hours to contribute to family income. By this attitude, the students have their attention divided between academic work and income generating activities. This ugly trend exists at a time academic performance of 
students is declining. Arising from above the question that comes to mind is; could this attitude have any effect on the academic performance of the students? This motivates the researcher to carry out this study.

\section{Purpose Of The Study}

The purpose of the study is to:

i. Find out the effect of street hawking on the academic performance of students in Social Studies in Junior Secondary School in Nasarawa state, Nigeria.

ii. Find out the difference between the academic performance of female students in social studies who participate in street hawking and their counterpart who do not in junior secondary schools in Nasarawa state, Nigeria.

iii. Find out the difference between the academic performance of male students who participate in street hawking and their counterpart who do not in junior secondary schools in Nasarawa state, Nigeria.

\section{Research Questions}

The following research questions were asked to guide the study:

i. What is the effect of street hawking on the academic performance of students in social studies in junior secondary schools in Nasarawa state, Nigeria?

ii. What is the difference between the academic performance of social studies female students who participate in street hawking and that of their counterpart who do not in junior secondary school in Nasarawa state, Nigeria?

iii. What is the difference between the academic performance of social studies male students who participate in street hawking and that of their counterpart who do not in junior secondary schools in Nasarawa state, Nigeria?

\section{Hypotheses}

The following hypothesis was formulated to answer the above questions:

Ho1: There is no significant difference between the academic performance of social studies students who participate in street hawking and that of their counterpart who do not in junior secondary schools in Nasarawa state, Nigeria.

Ho2: There is no significant difference between academic the performance of social studies female students who participate in street hawking and that of their counterpart who do not in junior secondary schools in Nasarawa state, Nigeria.

Ho3: There is no significant difference between the academic performance of social studies male students who participate in street hawking and that of their counterpart who do not in junior secondary school in Nasarawa state, Nigeria.

\section{Methodology}

The study design is a quasi-experimental that employed post-test only. The experimental and control group were located at two different schools. Through purposive sampling technique, the study involved a total of 100 subjects, 50 males and 50 females respectively from Government Junior secondary school, Akwanga and Government junior Secondary School, Gudi in Akwanga LGA of Nasarawa state. The students who participated in the experimental group were selected having been identified by their form masters through attendance register. The instrument used for the study, social studies performance test (SSPT) was designed by the researcher from the topics for the term in social studies. The academic committee of the respective schools validated the instrument. The test consisted of ten multiple-choice items. The experiment group is students who are engaged in street hawking and the control group is those who are not. The administration of the test was during the week of test in first term, 2013/2014 academic session. The responses of the subjects were scored two marks each for correct answers. The total marks obtainable are 20 . The data was subjected to t-test statistical analyses.

\section{Research question 1}

\section{Results}

What is the effect of street hawking on the academic performance of students in social studies in junior secondary schools in Nasarawa state, Nigeria?

Table 1: $\quad$ T-test of scores of students in the Experimental and Control Groups

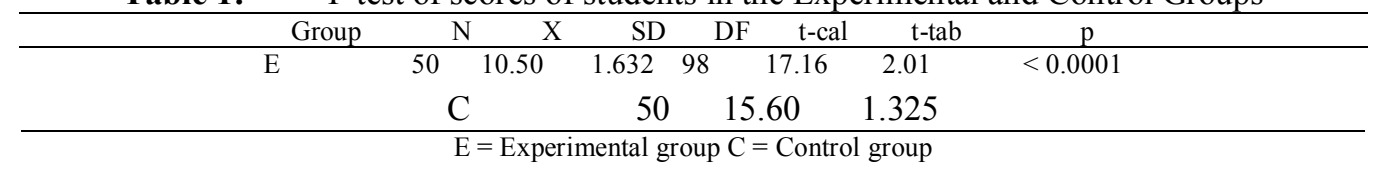


As shown in table 1 the performance mean score of the experimental group is 10.50 while that of the control group is 15.60 . Which mean that social studies students who participate in street hawking performed lower than there counterpart who do not. It is therefore concluded that street hawking have negative effect on academic performance of students in social studies in junior secondary schools in Nasarawa state.

\section{Research question 2}

What is the difference between the academic performances of social studies female students who participate in street hawking and that of their counterpart who do not in junior secondary schools in Nasarawa state, Nigeria?

Table 2: $\quad$ T-test of scores of female students in the Experimental and Control Groups

\begin{tabular}{cccccccccc}
\hline \multicolumn{2}{c}{ Group } & Sex & $\mathrm{N}$ & $\mathrm{X}$ & $\mathrm{SD}$ & $\mathrm{DF}$ & $\mathrm{t}$-cal & $\mathrm{t}$-tab & $\mathrm{p}$ \\
\hline $\mathrm{E}$ & $\mathrm{F}$ & 25 & 10.88 & & 1.716 & 48 & 10.70 & 2.02 & $<0.0001$ \\
& & & $\mathrm{C}$ & $\mathrm{F}$ & 25 & 15.56 & 1.386 & \\
\hline
\end{tabular}

$\mathrm{E}=$ Experimental group $\mathrm{C}=$ Control group

Table 2 indicates that the performance mean score of the experimental group is 10.88 while that of control group is 15.56. This means that there is a significant difference in their performance in favour of control group. It is concluded that. female students who participate in street hawking performed lower than their counterpart who do not.

\section{Research Question 3}

What is the difference between the academic performance of social studies male students who participate in street hawking and their counterpart who do not in junior secondary schools in Nasarawa state, Nigeria?

Table 3: T-test of scores of male students in the Experimental and Control Groups.

\begin{tabular}{ccccccccc}
\hline Group & Sex & $\mathrm{N}$ & $\mathrm{X}$ & $\mathrm{SD}$ & $\mathrm{DF}$ & $\mathrm{t}$-cal & $\mathrm{t}$-tab & $\mathrm{p}$ \\
\hline $\mathrm{E}$ & $\mathrm{M}$ & 25 & 10.12 & 1.481 & 48 & 13.92 & 2.02 & $<0.0001$ \\
$\mathrm{C}$ & $\mathrm{M}$ & 25 & 15.64 & 1.317 & & & \\
\hline
\end{tabular}

Table 3 shows that the performance mean score of the experimental group is 10.12 while that of the control group is 15.64. This means that, there is a significant difference in their performance in favour of the control group. It is concluded that, male students who participate in street hawking perform lower than their counterpart who do not.

\section{Testing Of Hypotheses}

The hypotheses as stated earlier on were tested using t-test statistical method. They are as follows:

\section{HYPOTHESES 1}

There is no significant difference between the academic performance of social studies students who participate in street hawking and that of their counterpart who do not in junior secondary schools in Nasarawa state, Nigeria.

Table 1 shows that the $t$-cal value (17.16) is greater than $t$-tab value (2.01). Therefore, since the $t$-cal value is greater than the t-tab value, the null hypotheses is rejected. This means there is a significant difference between the academic performance of students who participate in street hawking and that of their counterpart who do not in junior secondary schools in Nasarawa state, Nigeria.

\section{HYPOTHESES 2}

There is no significant difference between the academic performance of social studies female students who participate in street hawking and that of their counterpart who do not in junior secondary schools in Nasarawa state, Nigeria.

Table 2 shows that the $t$-cal value (10.70) is greater than $t$-tab value (2.02). Therefore, since the $t-$ cal value is greater than the t-tab value, the null hypotheses is rejected. This means, there is a significant difference between the academic performance of social studies female students who participate in street hawking and that of their counterpart who do not in junior secondary schools in Nasarawa state, Nigeria. 


\section{HYPOTHESES 3}

There is no significant difference between the academic performance of social studies male students who participate in street hawking and that of their counterpart who do not in junior secondary school in Nasarawa state, Nigeria.

Table 3 shows that the $t$-cal value (13.92) is greater than $t$-tab value (2.02). Therefore, since the $t$-cal value is greater than the t-tab value, the null hypotheses is rejected. This means, there is a significant difference between academic performance of social studies male students who participate in street hawking and that of their counterpart who do not in junior secondary school in Nasarawa state, Nigeria.

\section{Discussion Of Finding}

This study investigated the effect of street hawking on academic performance of students in social studies in junior secondary schools in Nasarawa state. It found that street hawking has negative effect on the academic performance of students in social studies in junior secondary schools in Nasarawa state, Nigeria. The findings which reveals that social studies students who participate in street hawking perform lower than their counterpart who do not confirms earlier study (Farauta, 2013), which found that students in practical Agriculture who engaged in street hawking performed poorly than their counterpart who do not. The result of hypotheses one, two and three reveals that there is a significant difference between the academic performance of social studies students who participate in street hawking and that of their counterpart who do not. This concurs with the finding of Farauta (2013), which shows a significant difference between the academic performances of students in practical Agriculture who participate in street hawking and that of their counterpart who do not. The result of the present study is expected because students who engage in income generating activities lack the opportunity to revise their notes, do homework and rest after school, which would have, improves their academic performance. Students in the study area hawk goods in morning before going to school and continue after until late night. This takes away the time they could have used to study. At times, these students were seen in school uniforms selling goods at railway crossing in Gudi and military checkpoint at Alushi during weekdays, which shows that they often missed classes. Attendance in school is necessary for improved academic performance (Nyame, 2010) which means that poor attendance has contributed to the poor academic performance of social studies students who engaged in hawking in the study area. In addition to the above, street hawking contributes to students' moral laxity, laziness and truant behavior (Ugodulunwa, et al 2004; Udoh, \& Joseph, 2012) capable of negatively influencing their academic performance. Social studies inculcate morality and good virtues in students, could it be that street hawking is capable of impeding achievement of the objectives of the course? If these children are taking off the street, it will enable them focus on their study and therefore, perform better in school. This calls for public enlightenment on the effect of street hawking, legislation against the act and will to enforce it by authority concern.

\section{Recommendations}

Base on the finding of this study, the following recommendations have been proffered: There is the for government continuous enlightenment of parents on the effect involving their children in street hawking and the importance of education. This becomes necessary so that parent look for other means of sustaining the family rather than use their children. There the need for government to create more job opportunities so that citizens would be employed to enable then carter for family needs. Government should make education free at all levels so that the less privileged children would have the opportunity to be educated. Government should legislate against involving school age children in hawking and punish parent, guardian and caregiver who go against it.

\section{References}

[1]. Anumaka, I.B. (2012) Child Labour: Impact On Academic Performance And Implication: A Case of North East Uganda. Journal of Educational Science and Research. 2, (2): pp 12-18

[2]. Arhedo, F.O. Aluede, O. and Arhedo, P.A. (2011) Incidence Of ChildLabour Among Secondary School Students in Benin Metropolis of EdoState, Nigeria. The Counselor. Official Publication of the CounselingAssociation of Nigeria. (CASSON) 29 (1):21-31.

[3]. Ashimolowo, O.R. , Aromolaran, A.K. and Inegbedion, S.O. (2010) ChildStreet Trading Activities and its Effects On The Educational AttainmentOf Its Victims In Epe Local Government Area Of Lagos State. JournalOf Agricultural Science. 2(4):211220. Www. cesenet.org/jas/

[4]. Editorial (2013, June, 25) Poor School Enrolment And Nigeria's FutureThe Guardian, pp 14.

[5]. Ekanem, S., Apebende, E.U. and Ekefre, E.N. (2008) Learning Environmentand Pupils Academic Performance: Implication for Counseling. TheCounselor. Official Journal of Counseling Association of Nigeria. (CASSON) 29 (1):32-42

[6]. Ezenwa, M. (2011) Symptoms of Psychopathology Among Street Hawkersin Enugu Metropolis Nigeria. Ife Psychologia: 19(1) retrieved on 29 April 2013 fromhttp://dx.doi.org/10.4314/ifep.v19i1.645

[7]. Farauta, K. (2013) Effect Of Street Hawking On The Academic Performance Students In Practical Agriculture A Case Of Secondary Schools In Taraba State. Journal of Education and Practice,4(15). Retrieved on 20 April 2014 from www.iiste.org 
[8]. Matthias, O. and Dada, O. (2013). A Sociological Investigation Of The Determination Factors And The Effect Of Child Street Hawking In Nigeria: Agege, Lagos State, Under Survey. International Journal ofAsian Social Science. 3(1):114-137 Retrieved on 29. April 2013 from http://www.aessweb.com/journal -detail php?id= 5007.

[9]. Ndem, B.E., Micheal, B. and Awa O.C. (2012) Child Labour In Nigeria And Its Economic Implication- A Case Study of Calabar Municipality. Research On Humanities And Social Sciences. www.iiste.org.

[10]. Nseubasi, A. and Oluwabamide, A.J. (2010) The Menace of Child Abuse in Nigeria: A case Study of Street Hawking In Uyo, Akwa Ibom State. JSOC SCI. 24(3):189-192. Retrieved On 29/04/2013 from www.krepublishers.com/.../JSS-24-3- 18910-972 Nseubasi-A-Tt-pdf

[11]. Nyame, G. (2010) Relationship Between Students' Class AttendancePerformance. The Case

Of Junior High School In The Kumasi,Metropolis. Unpublished Med. Thesis Submitted to the Institute For Educational Planning And Administration Of The Faculty Of Education, University Of Cape Coast, Ghana

[12]. Okon, C. P. (2005) Students Perception of Teachers Classroom Management and Performance in Social studies in Junior Secondary School Certificate Examination. The Jos Journal of Education. 7(2):80-88.

[13]. Okoji, O. O. (2013) Effect Of Socio-Economic Status Of Educational Attainment Of Female Secondary School Students In Rivers State Of Nigeria. Gender \& Behaviour:11(1) pp:5162-5166.

Udoh, N. A. and Joseph, E.U. (2012) Behavioural Problems of Juvenile Street Hawkers in Uyo Metropolis, Nigeria. World Journal Of Education 2(1):137-144 URL http://dx.doi.org/10.5430/wje.wje.v2nlp137.

[15]. Ugochukwu, E.F., Okeke, K.N., Onubogu, C.U and Edokwe, E.S. (2012) Socio-demographic Characteristics Of Child Street Vendor In Nnewi Nigeria. Niger J paed. 39(4):174 Doi:http://dx.doil.org/10.4314/njp.v39i4,5.

[16]. Ugodulunwa, C.A. Anakwe, A.I and Mustapha, Y.A. (2004) Behavioural Problems of Street Hawking Children in Jos Metropolis. The Nigerian Educational Psychologist. 24-33.

[17]. Usulor, B.E. (2012) Effect of Cooperative Learning Instructional Strategy on Junior Secondary School Students Achievement in Social Studies. Nigerian Journal of Social Studies and Civic Education.2 (1):pp68-79. 